\title{
Temperature dependence of bacterial specific growth rates on the continental shelf of the East China Sea and its potential application in estimating bacterial production
}

\author{
Fuh-Kwo Shiah ${ }^{1, *}$, Gwo-Ching Gong ${ }^{2}$, Tzong-Yueh Chen ${ }^{1}$, Chung-Chi Chen ${ }^{3}$ \\ ${ }^{1}$ PO Box 23-13, Institute of Oceanography, and ${ }^{3} \mathrm{PO}$ Box 23-19, National Center for Ocean Research, \\ National Taiwan University, Taipei, Taiwan, ROC \\ ${ }^{2}$ Department of Oceanography, National Taiwan Ocean University, Keeloung, Taiwan, ROC
}

\begin{abstract}
To decipher the relative importance of temperature and substrate supply in regulating the spatial patterns of bacterial production and specific growth rates, field surveys in the continental shelf of the East China Sea and on board substrate (dissolved free amino acids) enrichment experiments were conducted in December 1997 and March 1998. The results suggested that there was a shift from temperature dominance inside the mid-shelf to substrate supply dominance outside the mid-shelf controlling the spatial variability of bacterial growth during the cold seasons. The $Q_{10}$ values for bacterial specific growth rates $(B \mu)$ derived from the winter $\left(Q_{10}=3.4 \pm 0.3\right)$ and the spring $\left(Q_{10}=3.3 \pm 0.3\right)$ were very similar and comparable with the values derived from other estuarine and coastal ecosystems $\left(Q_{10}=3.1\right.$ to 3.4$)$. Such a consistent relationship between temperature and $B \mu$ allows one to use sea-surface temperature (SST) and depth-integrated bacterial biomass to model depth-integrated bacterial production (IBP) inside the mid-shelf of the East China Sea. The $B \mu$ versus temperature curve, $\ln B \mu=-0.42+0.122( \pm 0.02) \times \mathrm{SST}$, derived from a previous study in the southern East China Sea was used to simulate IBP. The total difference between the measured IBP and the simulated IBP is $<20 \%$.
\end{abstract}

KEY WORDS: Continental shelf $\cdot$ East China Sea $\cdot$ Kuroshio $\cdot Q_{10} \cdot$ Heterotrophic bacterioplankton Remote sensing $\cdot$ Modeling Resale or republication not permitted without written consent of the publisher

\section{INTRODUCTION}

Heterotrophic bacterioplankton are the major organisms responsible for the decomposition of dissolved organic carbon (DOC; Fuhrman 1992 and citations therein), which constitutes $>90 \%$ of the organic carbon pool in the ocean. Bacterial production and specific growth rates play a key role in determining what is actually left over or available for DOC export (Carlson et al. 1994, Carlson \& Ducklow 1995, Hansell \& Carlson 1998). On an areal basis, the continental shelf comprises $<10 \%$ of the world ocean. These ecosystems, however, could have a very important effect on global carbon cycling (Mantoura et al. 1991, Wong et al. 2000), due to large

*E-mail: fkshiah@ccms.ntu.edu.tw standing stocks of organic carbon as well as high rates of primary production. However, the actual role of these systems as sinks or sources of $\mathrm{CO}_{2}$ is not clear (Smith \& Hollibaugh 1993, Wong et al. 2000). A clear understanding of which environmental factors regulate bacterial growth and thus carbon consumption under a variety of conditions may provide insight into this issue.

It is well known that, when other factors are not limiting, the effects of temperature $(T)$ on many biological processes can be modeled (Day et al. 1989) using an Arrhenius expression: $y=a \mathrm{e}^{b T}$ or $\ln y=\ln a+b T$, where ln $a$ and $b$ represent intercept and slope respectively. For example, the $Q_{10}$ (the increase of rate parameter for each $10^{\circ} \mathrm{C}$ rise in temperature) values of phytoplankton optimal growth rate range between 1.88 and 2.30 (Eppley 1972). Bacteria are considered to have 

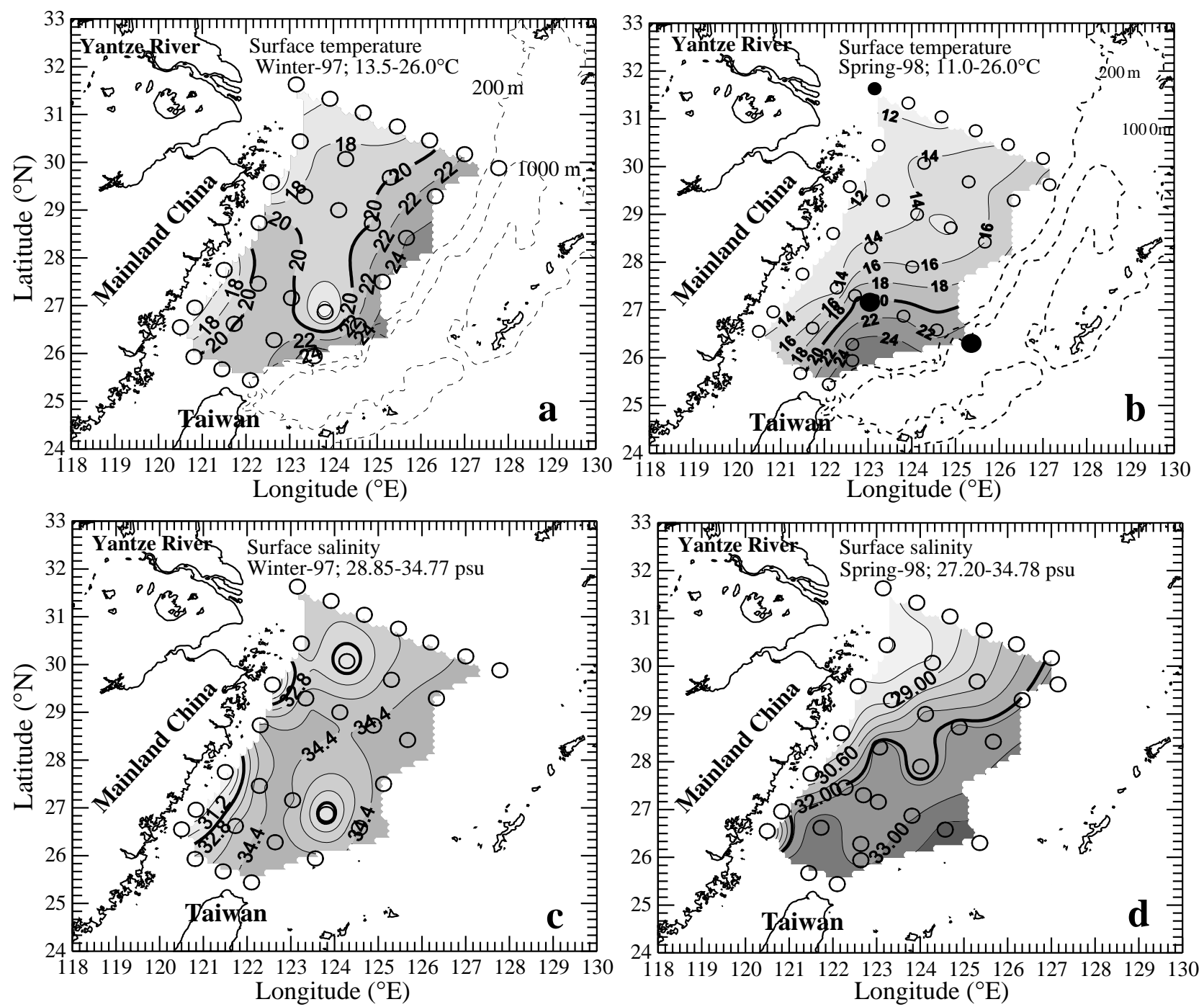

Fig. 1. Contours for surface values of $(\mathrm{a}, \mathrm{b})$ temperature, $(\mathrm{c}, \mathrm{d})$ salinity, $(\mathrm{e}, \mathrm{f})$ nitrate concentrations and $(\mathrm{g}, \mathrm{h})$ chlorophyll concentrations showing sampling stations in the East China Sea of winter 1997 (a, c, e and g) and spring 1998 (b, d, f and h). Solid circles in (b) indicate stations where substrate enrichment experiments were performed. Bold lines in (a-d) indicate the $20^{\circ} \mathrm{C}$ isotherms and the 32.0 psu isohalines respectively. Dashed lines indicate bottom depth in meters

higher $Q_{10}$ values than algae (Shiah et al. 1999, 2000 and citations therein). Recent studies (White et al. 1991, Shiah et al. 1999 and citations therein) have shown that seasonal bacterial specific growth rates followed the Arrhenius equation in neritic ecosystems with $Q_{10}$ values $>3.0$. By analyzing the correlations between bacterial rate parameters and other field variables, Shiah et al. $(1999,2000)$ suggested that bacterial growth on the inner shelf of the East China Sea (ECS) is not limited by substrate supply but by temperature during cold seasons, while on the outer shelf, the situation is reversed. They also suggested that the $Q_{10}$ for bacterial specific growth rates seemed comparable over a range of temporal and spatial scales. To ascer- tain how general these phenomena might be in the shelf ecosystem, 2 large area field surveys and 3 experiments with dissolved free amino acid mixture enrichment were conducted in the continental shelf of the ECS in winter and spring.

\section{MATERIAL AND METHODS}

Study site. Data were collected from the 2 cruises conducted on the continental shelf of the ECS north of Taiwan (Fig. 1) during December of 1997 (32 sampling stations) and early March of 1998 (34 sampling stations). Seawater was collected from a SeaBird CTD- 

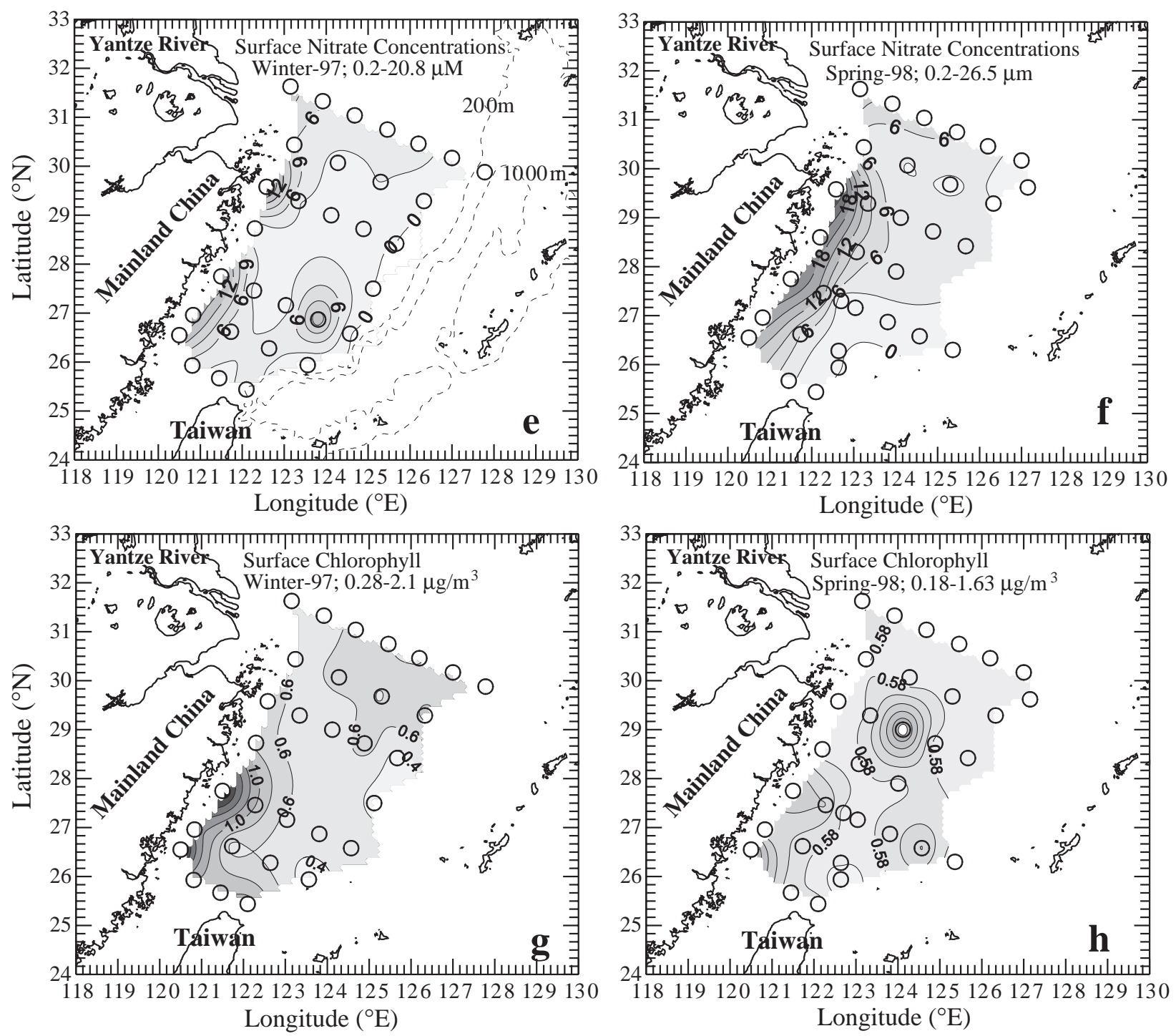

Fig. 1. (Continued)

General Oceanic Rosette assembly with 201 Go-Flo bottles. Light intensity was measured with a light meter (QSP200L; Biospherical). The depth of the euphotic zone was defined as $1 \%$ of the surface light level, and the bottom of the mixed layer was defined as the depth where the temperature was $0.5^{\circ} \mathrm{C}$ lower than at the surface (Levitus 1982).

Bacterial production, abundance and specific growth rates. Bacterial production and abundance were measured by ${ }^{3} \mathrm{H}$-thymidine incorporation (Fuhrman \& Azam 1982) and acridine orange epifluorescence microscopy (Hobbie et al. 1977) respectively (for details, see Shiah et al. 1999). For each station, duplicate samples were taken from 7 to 11 depths within the mixed layer $\left(Z_{\mathrm{m}}\right)$ or the euphotic zone $\left(Z_{\mathrm{e}}\right)$. With respect to substrate supply, the inte- grated bacterial abundance (and production) was obtained by integrating (trapezoidal method) over $Z_{\mathrm{m}}$ or $Z_{\mathrm{e}}$ depending on which one was deeper at the given station. Bacterial thymidine incorporation rate per cell (bacterial specific growth rate, $B \mu$ ) was calculated by dividing the integrated bacterial production (IBP) by the integrated bacterial abundance (IBA). For the calculation of the $Q_{10}$ values, IBP and $B \mu$ derived from different sampling stations were natural-log transformed and a linear regression analysis was performed to calculate the slope $(b)$ of $\operatorname{lnIBP}$ (and $\ln B \mu$ ) versus sea-surface temperature $(\mathrm{SST})$; the $Q_{10}$ values were then calculated as $Q_{10}=$ $10^{4.3437 b}$.

Substrate enrichment experiments. Experiments were performed on the spring cruise at the 3 sta- 
tions (Fig. 1b) that represented the inner-, mid- and outer-shelf waters (Table 1). At each station, whole surface water samples were pre-incubated at in situ (Table 1) and 2 to 3 other temperatures (see Fig. 4) in sixteen, 2.01 opaque polycarbonate bottles for $1 \mathrm{~h}$, which was sufficient to allow adjustment to the new temperature. Then, a dissolved free amino acid mixture (DFAA; 15 amino acids, final conc. $=0.5 \mu M_{i}$ Shiah \& Ducklow 1994a) was added to 8 bottles (duplicates for each temperature treatment); the remaining bottles were used as controls. Bacterial production and cell abundance were sampled every $3 \mathrm{~h}$ for the first $12 \mathrm{~h}$ and then sampled every $6 \mathrm{~h}$ until the end of the experiment. The end of the lag period was defined as the time when bacterial production values in the DFAA treatments were significantly ( $p<0.01$, difference usually $>20 \%$ ) higher than those in the controls.

Primary production. Primary production was measured by the ${ }^{14} \mathrm{C}$ assimilation method (Parsons et al. 1984). In brief, 1 dark and 2 light 250 ml clean polycarbonate bottles (Nalgen) were filled with water samples taken from the euphotic zone. After inoculation with $\mathrm{H}^{14} \mathrm{CO}_{3}^{-}$(final conc. $=10 \mu \mathrm{Ci} \mathrm{ml}{ }^{-1}$ ), samples were incubated for 2 to $4 \mathrm{~h}$ in artificial light. Water temperature was maintained with running seawater. To simulate different light intensities, bottles were wrapped with neutral density filters permitting 85, 50, 25, 10 and $1 \%$ of the light to pass through. Following retrieval, the water samples were immediately filtered through Whatman GF/F $25 \mathrm{~mm}$ filters under low light and low pressure $(<100 \mathrm{~mm} \mathrm{Hg})$. The filters were placed in scintillation vials, and $0.5 \mathrm{ml}$ of $0.5 \mathrm{~N} \mathrm{HCl}$ was added to remove residual $\mathrm{H}^{14} \mathrm{CO}_{3}{ }^{-}$. Radioactivity was counted in a liquid scintillation counter (Packard 1600) after the addition of $10 \mathrm{ml}$ scintillation cocktail (Ultima Gold, Packard) into the vials.

Chlorophyll $a$ and nitrate concentrations. Chlorophyll $a$ and nitrate concentrations were measured

Table 1. In situ values of measured variables for samples used in substrate enrichment experiments in spring 1998

\begin{tabular}{|c|c|c|c|c|}
\hline Variable & Units & $\begin{array}{c}\text { China Coastal } \\
\text { Waters }\end{array}$ & $\begin{array}{c}\text { Mid-shelf } \\
\text { Mixed Waters }\end{array}$ & $\begin{array}{l}\text { Kuroshio } \\
\text { Waters }\end{array}$ \\
\hline Temperature & ${ }^{\circ} \mathrm{C}$ & 11 & 20 & 25 \\
\hline Salinity & psu & 32.20 & 34.29 & 34.78 \\
\hline Nitrate & $\mu \mathrm{M}$ & 11.0 & 0.4 & 0.25 \\
\hline Chlorophyll & $\mathrm{mg} \mathrm{m}^{-3}$ & 0.87 & 0.52 & 0.39 \\
\hline $\begin{array}{l}\text { Bacterial TdR } \\
\text { incorporation rate }\end{array}$ & $\mathrm{pM} \mathrm{h}^{-1}$ & 1.67 & 2.07 & 1.17 \\
\hline $\begin{array}{l}\text { Bacterial } \\
\text { abundance }\end{array}$ & $\times 10^{9}$ cell $\mathrm{l}^{-1}$ & 0.79 & 0.28 & 0.25 \\
\hline $\begin{array}{l}\text { Bacterial } \\
\text { turnover rates }\end{array}$ & $\times \underset{\text { cell }^{-1} \mathrm{~h}^{-1}}{10^{-21} \mathrm{~mol} \mathrm{TdR}^{-}}$ & 0.06 & 0.21 & 0.13 \\
\hline
\end{tabular}

following the methods of Parsons et al. (1984). Water samples for nutrient analyses were frozen immediately with liquid nitrogen in clean $100 \mathrm{ml}$ polypropylene bottles. Nitrate was analyzed with a flow injection analyzer (Gong et al. 2000) and was reduced to nitrite with a cadmium wire, which was activated with a copper sulfate solution. For chlorophyll $a, 1$ to 21 of seawater were filtered through Whatman GF/F $25 \mathrm{~mm}$ filters, which were then immediately stored at $-20^{\circ} \mathrm{C}$. Back at the laboratory, the filters were ground in $10 \mathrm{ml} 90 \%$ acetone followed by extraction in a $4^{\circ} \mathrm{C}$ shaking incubator for $2 \mathrm{~h}$. After centrifugation at $1000(\sim 200 \times g) \mathrm{rpm}$ for $5 \mathrm{~min}$, the concentrations of chlorophyll $a$ in the supernatant were measured on a Turner fluorometer (model 10-AU-005).

\section{RESULTS}

\section{Hydrography}

The study area was characterized by strong gradients of temperature (Fig. $1 \mathrm{a}, \mathrm{b} ; 11$ to $26^{\circ} \mathrm{C}$ ), salinity (Fig. 1c,d; 27.20 to 34.78 psu), nutrients (Fig. 1e,f; surface nitrate, $<0.2$ to $26.5 \mu \mathrm{M}$ ) and high phytoplankton standing crops (Fig. 1g,h; surface chlorophyll $\approx 0.2$ to $2.1 \mathrm{mg} \mathrm{m}^{-3}$ ). Three water masses (Gong et al. 2000 and citations therein) could be identified in the ECS shelf (Table 1). They were the China Coastal Waters (the CCW; cold, eutrophic to mesotrophic with low salinity), the Kuroshio Waters (the $\mathrm{KW}_{\text {; }}$ warm and oligotrophic with high salinity) and the mid-shelf Mixed Waters (the MW; a mixture of the CCW and KW). Note that during spring, about half of the study area was covered by low salinity (<32 psu; Fig. 1d) waters, which indicated a strong influence from freshwater discharges. For both cruises, the mixed layer $\left(Z_{\mathrm{m}}\right)$ depth inside the mid-shelf was deeper than or similar to those of the euphotic zone $\left(Z_{\mathrm{e}}\right)$. Depths of $Z_{\mathrm{e}}$ were usually $<20 \mathrm{~m}$ in the CCW and $\sim 50 \mathrm{~m}$ in the MW. In the outer shelf area (the $\mathrm{KW}$ ), $Z_{\mathrm{e}}$ extended down to $\sim 100 \mathrm{~m}$ with a $Z_{\mathrm{m}}$ of $\sim 60 \mathrm{~m}$.

SST was used in our analysis for 2 reasons. SST reflected the spatial location of sampling stations (Fig. 1a,b), that is, the SST increased offshore. In addition, SST was identical to the average mixed layer temperature. Note that in areas adjacent to the Yantze River, the temperatures in spring 1998 were 2 to $3^{\circ} \mathrm{C}$ lower than in winter 1997 (Fig. 1b). 
Table 2. Intercepts, slopes and $Q_{10}$ values for natural-log transformed depth-integrated bacterial production (lnIBP) and bacterial turnover rates $(\ln B \mu)$ versus temperature for the $<20^{\circ} \mathrm{C}$ data collected from the 2 cold-season cruises. All equations are significant at the $p=0.01$ level

\begin{tabular}{|lcccccc|}
\hline Cruise & Variable & Intercept & Slope $( \pm$ SE $)$ & $Q_{10}$ & Sample size & $\mathrm{R}^{2}$ \\
\hline Winter & $\ln I B P$ & $+2.57^{\mathrm{a}}$ & $0.10^{\mathrm{b}}( \pm 0.02)$ & 2.46 & 20 & 0.65 \\
1997 & $\ln B \mu$ & -0.48 & $0.12( \pm 0.01)$ & 3.41 & 20 & 0.83 \\
Spring & $\ln \mathrm{IBP}$ & $+3.69^{\mathrm{a}}$ & $0.05^{\mathrm{b}}( \pm 0.01)$ & 1.68 & 23 & 0.67 \\
1998 & $\ln B \mu$ & -0.45 & $0.12( \pm 0.01)$ & 3.32 & 23 & 0.86 \\
a,b Different from each other at $\mathrm{p}=0.05$ level by analysis of covariance & & & \\
\hline
\end{tabular}

\section{Spatial patterns of bacterial measurements}

Depth-integrated bacterial production (IBP) during winter (37 to $\left.91 \times 10^{-9} \mathrm{~mol} \mathrm{TdR} \mathrm{m}^{-2} \mathrm{~h}^{-1}\right)$ and spring $(44$ to $104 \times 10^{-9} \mathrm{~mol} \mathrm{TdR} \mathrm{m}{ }^{-2} \mathrm{~h}^{-1}$ ) was low in cold (5 to $10^{\circ} \mathrm{C}_{i}$ inner shelf) and warm $\left(>22^{\circ} \mathrm{C}\right.$; outer shelf $)$ water areas (Fig. 2a). Below the $20^{\circ} \mathrm{C}$ isotherm (areas inside the mid-shelf; Fig. 1b), IBP was higher in spring than in winter. On the outer-shelf, IBP of both cruises decreased with increasing temperature and was positively correlated with the euphotic zone integrated primary production (IPP) in the outer-shelf areas (Fig. 3; $\mathrm{r}=0.85, \mathrm{n}=13, \mathrm{p}<0.001)$. This suggested that substrate supply could be more crucial in controlling bacterial

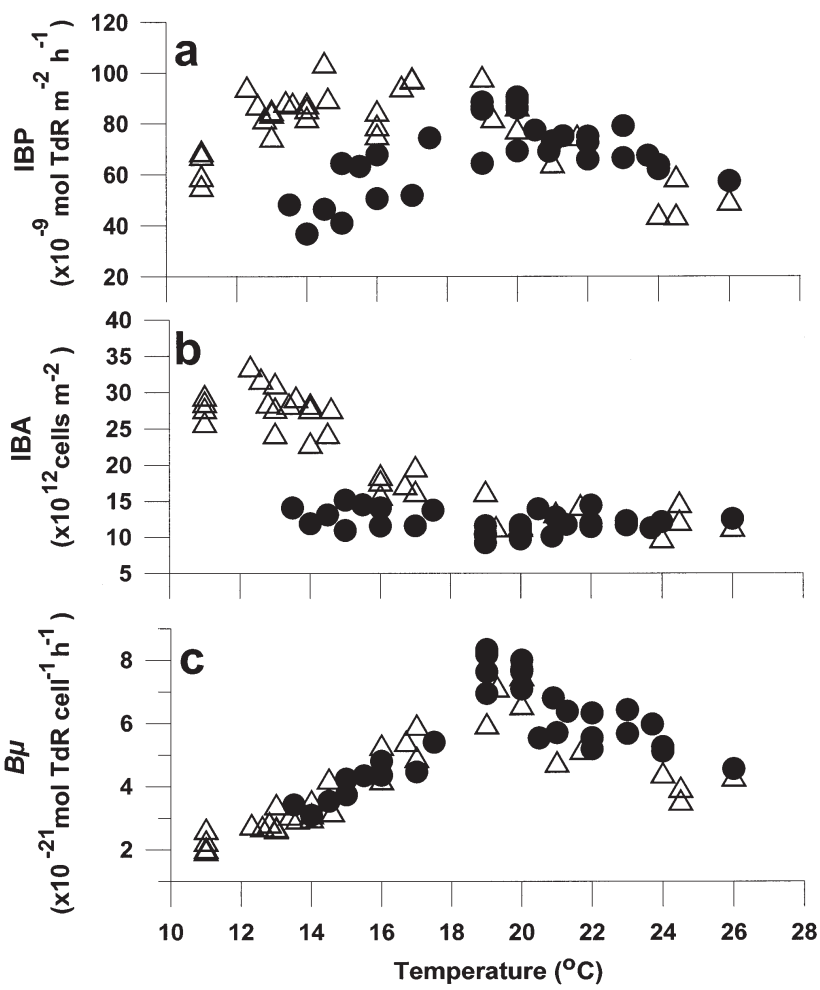

Fig. 2. Depth-integrated (a) bacterial production (IBP) and (b) abundance (IBA) and (c) specific growth rates $(B \mu)$ along the temperature gradient in winter $1997(\bullet)$ and spring $1998(\Delta)$ growth outside the mid-shelf. For the areas with a temperature $<20^{\circ} \mathrm{C}$, IBP was correlated with temperature (Table 2) but not with IPP (Fig. 3; p > 0.05, n = 46), which indicated that local substrate supply might not be the major controlling factor in regulating the spatial variability of IBP inside the mid-shelf (see also the results of the DFAA enrichment experiments).

In winter, depth-integrated bacterial abundance (IBA; 9 to $15 \times 10^{12}$ cells $\mathrm{m}^{-2}$ ) showed no pattern with SST (Fig. 2b), salinity or IPP (data not shown). In contrast, spring IBA (10 to $33 \times 10^{12}$ cells $\mathrm{m}^{-2}$ ) varied more than 3-fold, with higher values observed on the innershelf. It decreased offshore with increasing SST ( $\mathrm{r}=$ $-0.88, \mathrm{n}=33, \mathrm{p}<0.01)$ and salinity $(\mathrm{r}=-0.67, \mathrm{n}=33$, $\mathrm{p}<0.01$ ), and then remained more or less constant outside the mid-shelf. No significant relationship was observed between IBA and IPP inside the mid-shelf during spring; however, IBA was positively correlated with IPP $(r=0.63, n=13, p<0.001)$ on the outer-shelf.

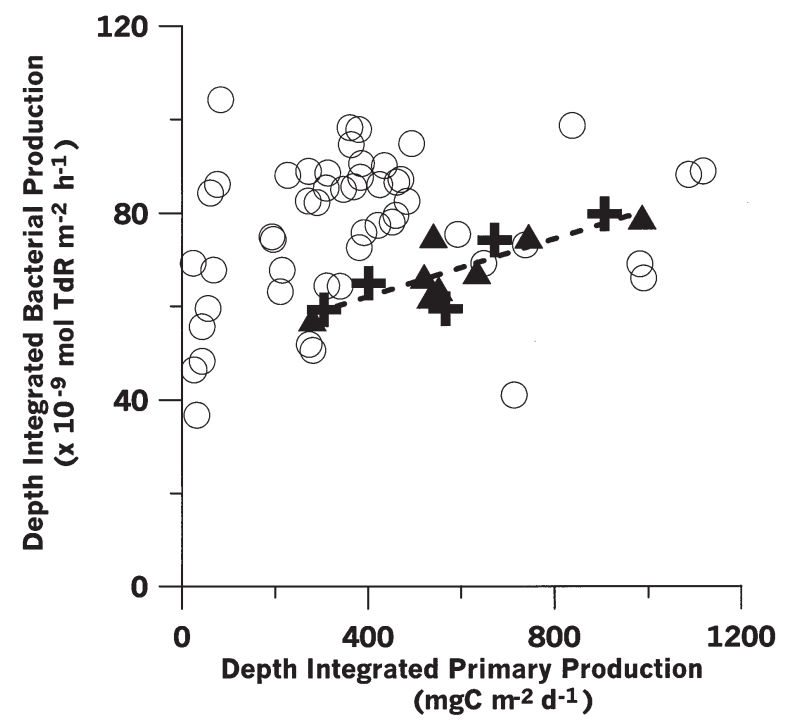

Fig. 3. Depth-integrated bacterial production (IBP) versus depth-integrated primary production (IPP). Outer-shelf data $\left(T>21^{\circ} \mathrm{C}, S>34.500 \mathrm{psu}\right)$ are shown for winter $1997(+)$ and spring $1998(\boldsymbol{\Delta})$. The relationship is IBP $=49+0.032( \pm 0.006)$ $\times \operatorname{IPP}\left(\mathrm{R}^{2}=0.72, \mathrm{n}=13, \mathrm{p}<0.001\right)$ 
Bacterial specific growth rates $\left(B \mu=\mathrm{IBP} / \mathrm{IBA}_{;} 2.0\right.$ to $8.3 \times 10^{-21} \mathrm{~mol} \mathrm{TdR} \mathrm{cell}{ }^{-1} \mathrm{~h}^{-1}$ ) of the 2 cruises showed similar patterns with SST (Fig. 2c). Values of $B \mu$ were low $\left(2\right.$ to $3 \times 10^{-21} \mathrm{~mol} \mathrm{TdR}$ cell ${ }^{-1} \mathrm{~h}^{-1}$ ) on the innershelf, they peaked at the mid-shelf $\left(7\right.$ to $8 \times 10^{-21} \mathrm{~mol}$ TdR cell ${ }^{-1} \mathrm{~h}^{-1}$ ) along the $20^{\circ} \mathrm{C}$ isotherm, and then they decreased to values ca 3 to $4 \times 10^{-21} \mathrm{~mol} \mathrm{TdR}$ cell $^{-1} \mathrm{~h}^{-1}$ in the outer-shelf area. For both cruises, no significant relationship was observed between $B \mu$ and IPP inside the mid-shelf. However, $B \mu$ was positively correlated with IPP $(\mathrm{r}=0.60, \mathrm{n}=13, \mathrm{p}<0.001)$ on the outer-shelf.

The relationships between IBP and SST for the $<20^{\circ} \mathrm{C}$ data were significant (Table 2). However, the $Q_{10}$ value for the spring IBP $\left(Q_{10}=1.68\right)$ was only $68 \%$ of that of the winter IBP $\left(Q_{10}=2.46\right)$. This could be ascribed to the different IBA during winter and spring (Fig. 2b; see 'Discussion and conclusions'). In contrast, the $Q_{10}$ values of $B \mu$ for the winter $\left(Q_{10}=3.41\right)$ and spring $\left(Q_{10}=3.32\right)$ were quite consistent.

\section{Substrate enrichment experiments}

Fig. 4 shows that when incubated at in situ temperatures (Table 1) the addition of DFAA does not enhance $B \mu$ (or bacterial production) within $21 \mathrm{~h}$ in the samples taken from the inner-shelf. On the other hand, $B \mu$ of the samples taken from the mid- and outer-shelf increased rapidly ( $<3$ to $5 \mathrm{~h}$ ) after the addition of DFAA. Note also that changing incubation temperature had a very similar effect on $B \mu$ in all 3 experiments; the lag periods required for bacteria to respond to DFAA enrichment were negatively correlated with incubation temperatures $(p<0.01)$.

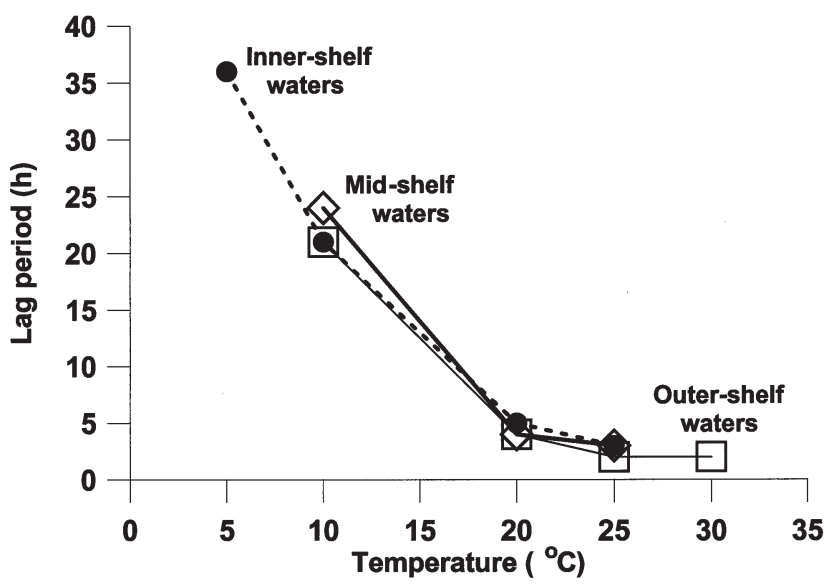

Fig. 4. Temperature effects on the lag period required for bacteria to respond to an enrichment of dissolved free amino acids. (৩) Inner-shelf waters; $(\diamond)$ mid-shelf mixed waters (3 treatments only); and ( $\square$ ) outer-shelf waters

\section{DISCUSSION AND CONCLUSIONS}

Several previous studies explicitly addressing spatial (Shiah et al. 1999, 2000), temporal (Shiah \& Ducklow 1994b, 1995) and cross-system (White et al. 1991) variation of $B \mu$ showed that the $Q_{10}$ for $B \mu$ varied within a narrow range of 3.13 to 3.42 in neritic ecosystems. All this evidence suggests that temperature dependency of $B \mu$ might be comparable across different temporal and spatial scales. A significant correlation of $B \mu$ with temperature indicates that during the cold seasons temperature, instead of substrate supply, probably was the major limiting factor for $B \mu$ inside the mid-shelf. In the outer-shelf region, the situation might be reversed. Values of IPP ( $\mathrm{r}=-0.88, \mathrm{n}$ $=13, \mathrm{p}<0.05)$, IBP and $B \mu$ decreased with increasing temperature outside the mid-shelf (Fig. 2a,c), and this implies that as the system becomes more oligotrophic (Fig. 1e,f), substrate control of bacterial growth becomes more significant (Figs. 3 \& 4; White et al. 1991, Shiah et al. 1999).

Different IBA values observed within the inner-shelf on the 2 cruises might be related to the different magnitude of interactions (mixing) between the KW and the CCW in the ECS shelf. During winter, the intrusion of the oligotrophic KW (Gong et al. 1996) into the ECS shelf and the low discharge rate of the Yantze River (Fig. 1c) might result in low IBA. During spring, the KW withdrew from the shelf and river discharge rates started to increase as indicated by a larger plume of cold, low salinity water along the coast of mainland China during spring 1998 (Fig. 1b,d), this might lead to more riverine bacteria in the inner-shelf area. Different strengths of removal processes (bacterivory and viral lysis) during these 2 cruises might also have resulted in distinct IBA. However, no conclusion could be made due to the lack of protozoan and viral data. Interestingly, although the values of spring IBP and IBA observed in the inner shelf (Fig. $2 \mathrm{a}, \mathrm{b}_{i}<14^{\circ} \mathrm{C}$ ) were at least 2 times higher than those of the winter, $B \mu$ of the 2 cruises behaved almost exactly the same with changing temperature (Fig. 2c). This once again indicates that the temperature response of $B \mu$ seems to be constant over the seasons.

The substrate enrichment experiments (Fig. 4) and the relationship of IPP versus IBP (Fig. 3) support the deduction of the transition of temperature control inside the mid-shelf to substrate control outside the mid-shelf. These findings also support the conclusion of several previous studies (Hollibaugh 1979, Wiebe et al. 1992, 1993), which suggested that the substrate effects on bacterial growth were temperature dependent. In addition, strong temperature regulation on $B \mu$ occurred only when substrate supply was high (Berman et al. 1994, Shiah \& Ducklow 1994a). 
Satellite remote sensing has become very promising in estimating primary productivity, although quite a few obstacles are still to be overcome. One intriguing question concerns whether SST, derived from either satellite or cruise measurement, can be used to estimate bacterial production for coastal environments within a limited temperature range and seasons. The distinct temperature response of IBP of the 2 cruises (Table 2) rules out the possibility of using SST to estimate IBP directly. However, the constancy of the $Q_{10}$ value of $B \mu$ may allow us to model IBP based on the measurements of SST and IBA, which can be quickly acquired by flow cytometry (Sieracki \& Viles 1990, Li et al. 1993). The $B \mu$ versus temperature $(\ln B \mu=-0.42+$ $\left.0.122 \pm[0.02] \times \mathrm{SST}, \mathrm{n}=22, \mathrm{R}^{2}=0.78, \mathrm{p}<0.01\right)$ relationship derived previously (Shiah et al. 1999) for the southern ECS was adopted to simulate IBP in this study. The modeled IBP and the measured IBP agree very well (Fig. 5), with slope and $R^{2}$ values of $0.87 \pm$ 0.08 and $73 \%$, respectively. The total difference $\{[(\Sigma$ measured IBP $-\Sigma$ modeled IBP) $/ \Sigma$ measured IBP] $\times$ $100 \%$ \} between them was $19 \%$.

There are 2 major limitations to this approach. It can be applied only to areas of the mid-shelf during cold seasons, and measurements of bacterial biomass or abundance are still required. However, for some modelers who do not have access to and some scientists who are not familiar with the use of (or not allowed to use) radioisotopes (i.e. ${ }^{3} \mathrm{H}$-thymidine and ${ }^{3} \mathrm{H}$-leucine) to estimate bacterial production, this approach may offer an alternative means of deriving IBP with an accuracy no less than ca $80 \%$ (Fig. 5).

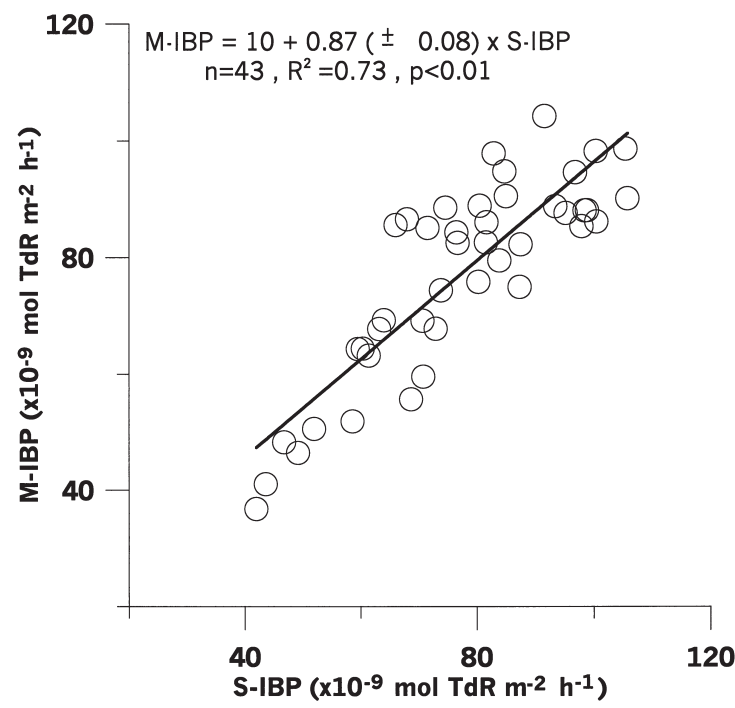

Fig. 5. Measured depth-integrated bacterial production (MIBP) versus the simulated values (S-IBP). The $B \mu$ versus SST curve $(\ln B \mu=-0.40+0.122[ \pm 0.02] \times \mathrm{SST})$ was adopted from Shiah et al. (1999)
Overall, this study systematically demonstrated a well-known but not fully developed theory which indicates that the temperature dependency of bacterial specific growth rates in high productivity ecosystems is comparable over different temporal and spatial scales during seasons (and areas) in which substrate supply is not limiting. With bacterial biomass data and reliable relationships of $B \mu$ with temperature, the depth-integrated bacterial production can be quickly and easily calculated, although limitations to this application are noted.

Acknowledgements. This research was supported by the NSC-Taiwan (grant no. NSC-88-2611-M002-006-K2). The NCOR contribution no. 25.

\section{LITERATURE CITED}

Berman T, Hoppe H, Gocke K (1994) Response of aquatic bacterial populations to substrate enrichment. Mar Ecol Prog Ser 104:173-184

Carlson CA, Ducklow HW (1995) Dissolved organic carbon in the upper ocean of the central Equatorial Pacific, 1992: daily and finescale vertical variations. Deep-Sea Res 42: 639-656

Carlson CA, Ducklow HW, Michaels AF (1994) Annual flux of dissolved organic carbon from the euphotic zone in the northwestern Sargasso Sea. Nature 371(29):405-408

Day JW, Hall CAS, Kemp MW, Yanez-Arancibia A (1989) Estuarine ecology. Wiley \& Sons, New York

Eppley RW (1972) Temperature and phytoplankton growth in the sea. Fish Bull 70(4):1063-1085

Fuhrman JA (1992) Bacterioplankton roles in cycling of organic matter: the microbial food web. In: Falkowski PG, Woodhead AD (eds) Primary productivity and biogeochemical cycles in the sea. Plenum Press, New York, p 361-383

Fuhrman JA, Azam F (1982) Thymidine incorporation as a measurement of heterotrophic bacterioplankton production in marine surface waters: evaluation and field results. Mar Biol 66:109-120

Gong CC, Shiah FK, Liu KK, Wen YH, Liang MH (2000) Spatial and temporal variation of chlorophyll a, primary productivity and chemical hydrography in the southern East China Sea. Cont Shelf Res 20(4/5):411-436

Hansell DA, Carlson CA (1998) Net community production of dissolved organic carbon. Global Biogeochem Cycle 12(3): 443-453

Hobbie JE, Daley RJ, Jasper S (1977) Use of nuclepore filters for counting bacteria by fluorescence microscopy. Appl Environ Microbiol 33(5):1225-1228

Hollibaugh JT (1979) Metabolic adaptation in natural bacterial populations supplemented with selected amino acids. Estuar Coast Shelf Sci 9:215-230

Levitus S (1982) Climatological atlas of the world ocean. NOAA professional paper, NOAA, Seattle

Li WKW, Irwin BD, Dickie PM (1993) Dark fixation of ${ }^{14} \mathrm{C}$ : variations related to biomass and productivity of phytoplankton and bacteria. Limnol Oceanogr 38(3):483-494

Mantoura RFC, Martin JM, Wollast R (1991) Ocean processes in global change. Wiley \& Sons, New York

Parsons TR, Maita Y, Lalli CM (1984) A manual of chemical and biological methods for seawater analysis. Pergamon Press, New York 
Shiah F, Ducklow HW (1994a) Temperature and substrate regulation of bacterial abundance, production and specific growth rate in Chesapeake Bay, USA. Mar Ecol Prog Ser 103:297-308

Shiah F, Ducklow HW (1994b) Temperature regulation of heterotrophic bacterioplankton abundance, production, and specific growth rate in Chesapeake Bay. Limnol Oceanogr 39(6):1243-1258

Shiah F, Ducklow HW (1995) Multi-scale variability in bacterioplankton abundance, production and specific growth rate in a temperate salt marsh tidal creek. Limnol Oceanogr 40(1):55-66

Shiah FK, Gong GC, Liu KK (1999) Temperature vs. substrate limitation of heterotrophic bacterioplankton production across trophic and temperature gradient in the East China Sea. Aquat Microb Ecol 17(3):247-254

Shiah FK, Liu KK, Kao SJ, Gong GC (2000) The coupling of bacterial production and hydrography in the southern East China Sea. Cont Shelf Res 20(4/5):459-477

Editorial responsibility: James Hollibaugh,

Athens, Georgia, USA
Sieracki ME, Viles CL (1990) Color image-analyzed fluorescence microscopy: a new tool for marine microbial ecology. Oceanography 3(2):30-36

Smith SV, Hollibaugh JT (1993) Coastal metabolism and the ocean organic carbon balance. Rev Geophys 31(1):75-89

White PA, Kalff J, Rasmussen JB, Gasol JM (1991) The effects of temperature and algal biomass on bacterial production and specific growth rate in freshwater and marine habitats. Microb Ecol 21:99-118

Wiebe WJ, Sheldon WM Jr, Pomeroy LR (1992) Bacterial growth in the cold: evidence for an enhanced substrate requirement. Appl Environ Microbiol 58:359-364

Wiebe WJ, Sheldon WM Jr, Pomeroy LR (1993) Evidence for an enhanced substrate requirement by marine mesophilic isolates at minimal temperatures. Microb Ecol 25:151-159

Wong GTF, Chao SY, Li YH, Shiah FK (2000) The Kuroshio Edge Exchange Processes (KEEP) Study - an introduction to hypotheses and highlights. Cont Shelf Res 20(4/5): 335-347

Submitted: June 22, 1999; Accepted: April 11, 2000

Proofs received from author(s): July 14, 2000 